\title{
Educational AND PEDAgogicAl ROLE OF THE FAMILY IN SHAPING THE SECURITY CULTURE AND SENSE OF SECURITY IN CYBERSPACE
}

\author{
EDUKACYJNO-WYCHOWAWCZA ROLA RODZINY \\ W KSZTAŁTOWANIU KULTURY I POCZUCIA \\ BEZPIECZEŃSTWA W CYBERPRZESTRZENI
}

\begin{abstract}
Cyberspace, virtual space, an illusion of the world - it facilitates the exchange and storage of information, simplifies the communication between humans and computers, as well as between citizens. Despite representing an opportunity for the development of an individual, it poses a threat to the security of its users, especially the juvenile ones.

The aim of the article is to portray the threats of the cyberworld and the possibilities of addressing them through parents' appropriate attitudes and actions. Basing on the analysis of relevant literature and statistical data it can be inferred that a rising percentage of juveniles display symptoms of addiction. Furthermore, according to data provided by Statistics Poland, the access of children and youth to digital media has been steadily increasing since 2012. In 2017, as many as 98,9 per cent of households with children had Internet access. The ubiquitous availability of digital media may result in a constant increase in pathological behaviours of children in the cyberworld, which will evolve under the influence of changes in society. Dangerous games such as Blue Whale, Fire Fairy, MOMO Challenge and phenomena such as cyberbullying, cyberpornography, online paedophilia and sexting do not only influence the personality and daily life
\end{abstract}


of young Internet users, but also pose an actual threat to their life and health. It is, therefore, of profound importance to educate parents in order to enable them to guard their children in the Internet and instill appropriate behaviour.

The article is divided into two parts. The first part explains and discusses the perils present in the cyberspace. The second part comprises reflection upon the pedagogical and educational role of the family and the possibilities of protecting the juveniles in the Internet by means of developing a security culture in the digital environment. The author postulates that the lack of conscious action of guardians prevents them from addressing the threats of the cyberworld in an effective manner, resulting in the emergence of antisocial individuals, who are unable to live and function in their surroundings.

\section{STRESZCZENIE}

Cyberprzestrzeń, przestrzeń wirtualna, iluzja świata ułatwia wymianę i gromadzenie informacji, jak również komunikację pomiędzy człowiekiem a komputerem oraz pomiędzy obywatelami. Stanowi szansę dla rozwoju jednostki, ale jest także zagrożeniem dla bezpieczeństwa, przede wszystkim osób małoletnich.

Celem artykułu jest ukazanie zagrożeń cyberświata i możliwości ich niwelowania dzięki właściwym postawom i zachowaniom rodziców. Na podstawie analizy literatury i danych statystycznych można stwierdzić, iż u coraz większej grupy małoletnich zauważalne są objawy uzależnienia, a obserwując dane Głównego Urzędu Statystycznego, zauważa się, że dostęp dzieci i młodzieży do mediów cyfrowych od 2012 r. wykazuje stałą tendencję wzrostową (w 2017 r. aż 98,9\% gospodarstw, w których są dzieci, miało dostęp do Internetu), co może powodować, że problem patologicznych zachowań dotyczących dzieci w cyberświecie również będzie wzrastał i stale ewoluował wraz ze zmianami zachodzącymi w społeczeństwie. Niebezpieczne gry, takie jak: Błękitny Wieloryb, Wróżka ognia, Momo Challenge, zjawiska takie jak: cyberbullying, cyberpornografia, pedofilia w sieci, seksting, wpływają nie tylko na ich osobowość i funkcjonowanie, ale stanowią realne zagrożenie dla życia i zdrowia dzieci. Dlatego tak ważne jest edukowanie nie tylko dzieci, ale również ich rodziców, tak by mogli strzec swoich podopiecznych w sieci, ale także by uczyli ich prawidłowych zachowań.

Artykuł został podzielony na dwie części. W pierwszej Autorka wyjaśnia i omawia zagrożenia istniejące w cyberprzestrzeni. Druga część to rozważania o edukacyjnej i wychowawczej roli rodziny i możliwościach ochrony przed tymi zagrożeniami poprzez m.in. kształtowane kultury bezpieczeństwa małoletnich w cyberświecie. Autorka stawia tezę, iż bez świadomych działań opiekunów nie można skutecznie przeciwdziałać zagrożeniom związanym $\mathrm{z}$ cyberświatem, a tym samym doprowadza się do kształtowania się jednostek aspołecznych, nieumiejących żyć i poprawnie funkcjonować w świecie realnym. 
KEYWORDS: security, cyberspace, threat, risky behaviours, dangerous games, cyberbullying

SŁOWA KLUCzOWE: bezpieczeństwo, cyberprzestrzeń, zagrożenie, zachowania ryzykowne, niebezpieczne gry, przemoc $w$ sieci

\section{WPROWADZENIE}

Każdy obywatel, nawet ten najmniejszy, dąży do zaspokojenia swoich podstawowych potrzeb. Jedną z nich jest bezpieczeństwo stanowiące wartość nadrzędną, która jest celem każdego narodu. Sam termin „bezpieczeństwo" jest różnie rozumiany. Najczęściej utożsamia się go z brakiem zagrożenia. Według Waldemara Kitlera bezpieczeństwo narodowe to najważniejsza wartość, potrzeba narodowa i priorytetowy cel działania państwa, jednostek i grup społecznych, a jednocześnie proces obejmujący różnorodne środki, gwarantujące trwały, wolny od zakłóceń byt i rozwój narodowy, obronę i ochronę państwa jako instytucji politycznej oraz ochronę jednostek i całego społeczeństwa, ich dóbr i środowiska naturalnego przed zagrożeniami, które w znaczący sposób ograniczają jego funkcjonowanie lub godzą w dobra podlegające szczególnej ochronie (Kitler, 2011, s. 25). W znaczeniu ogólnospołecznym pojęcie to obejmuje zabezpieczenie takich potrzeb jak: potrzeba istnienia, przetrwania, stabilności, tożsamości, niezależności, ochrony jakości życia, rozwoju (Nowak, Nowak, 2011, s. 12). Istotą bezpieczeństwa jest: gwarancja przetrwania podmiotu w stanie nienaruszonym dająca możliwość fizycznego istnienia oraz możliwość swobodnego rozwoju społecznego (Loranty, 2004, s. 5). Sam stan bezpieczeństwa może być postrzegany subiektywnie lub obiektywnie i może przyjmować różne postaci, takie jak:

- stan braku bezpieczeństwa - cechujący się dużym rzeczywistym zagrożeniem i prawidłową diagnozą;

- stan obsesji - cechujący się pojmowaniem nieznacznego zagrożenia jako dużego;

- stan fałszywego bezpieczeństwa - poważne zagrożenie odbierane jest wówczas jako niewielkie;

- stan bezpieczeństwa - charakteryzujący się tym, iż zagrożenie jest niewielkie, natomiast jego diagnoza i postrzeganie jest prawidłowe (Leszczyński, 2011, s. 14). 
W literaturze przedmiotu widoczne są różne rodzaje zagrożenia bezpieczeństwa, takie jak: zagrożenia polityczne, militarne i „niekonwencjonalne", które uderzają w egzystencjalne i biologiczne podstawy trwania narodu (Leszczyński, 2011, s. 62). Interesującego usystematyzowania zagrożeń dokonała Jolanta Supińska, dzieląc je następująco:

- przyroda - ekosfera - stanowi zagrożenie, jeśli jest niszczona przez człowieka, a także gdy on nad nią dominuje, czego efektem są np. klęski żywiołowe;

- technika - stworzona przez człowieka technosfera - stanowi zagrożenie, gdy jest niedoskonała, ale też gdy jest rozwinięta i zrozumienie jej przerasta możliwości człowieka;

- system społeczno-ekonomiczno-polityczny i uwarunkowania konkretnych zachowań jednostek;

- agresja innych jednostek;

- sama osoba zagrożona, stająca się zagrożeniem dla siebie czasem wbrew własnej woli (m.in. przez niedomagania wrodzone i nabyte, czyny autodestrukcyjne i inne czynniki) (Leszczyński, 2011, s. 50-60).

To właśnie rozwój i dostępność techniki powodują, że przy całym pozytywnym jej aspekcie nie można nie zauważyć, jak wielkie zagrożenie może ona stanowić dla państw, społeczeństw i jednostek. Zagrożenia w świecie wirtualnym, w cyberprzestrzeni, rozumianej jako iluzja świata rzeczywistego, powstałej dzięki narzędziom teleinformatycznym ułatwiającym wymianę, gromadzenie i udostępnianie informacji, komunikację pomiędzy człowiekiem a komputerem (Gogołek, Cetra, 2014, s. 207), stały się poważnym problemem, gdyż często są one niewidoczne lub zauważane zbyt późno. Szczególnie zagrożone są osoby małoletnie, których psychika jest bardzo plastyczna. Coraz więcej dzieci ma dostęp do komputera, Internetu czy telefonu.

Od roku 2012 zauważalny jest stały wzrost dostępu do Internetu gospodarstw, w których są dzieci. To powoduje, że problem zagrożeń bezpieczeństwa małoletnich w sieci bez podejmowania działań profilaktycznych będzie narastał. 
Wykres 1.

Dostęp do Internetu w gospodarstwach domowych (dane procentowe dotyczące ogółu gospodarstw) w latach 2012-2017

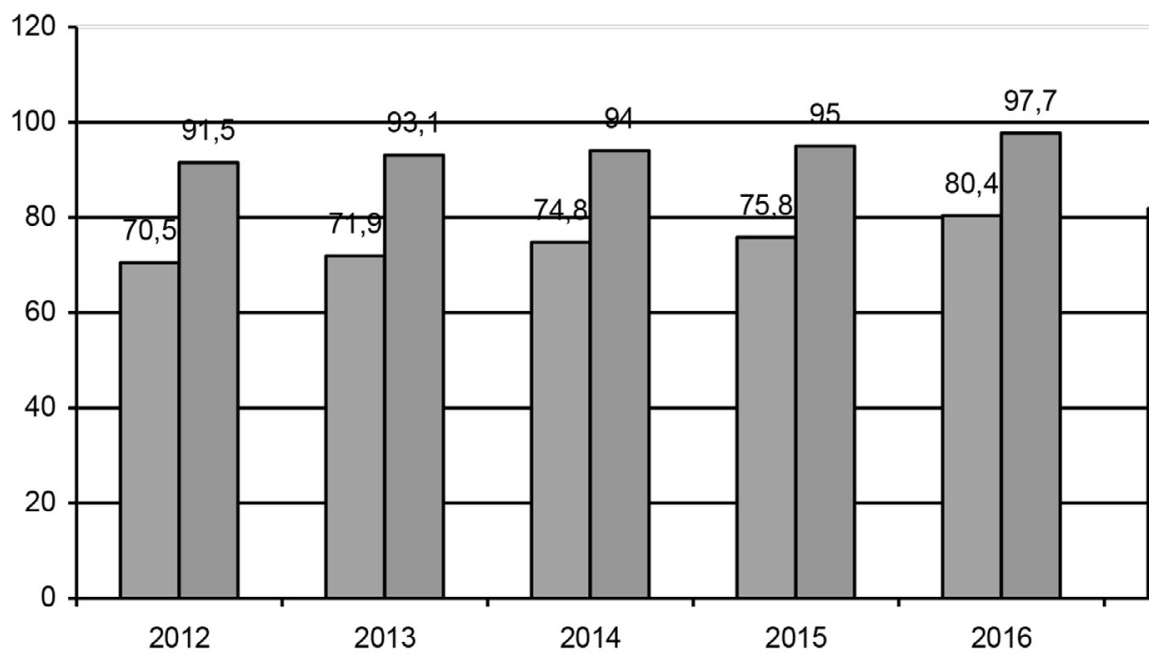

Źródło: opracowanie własne na podstawie: Główny Urząd Statystyczny, Urząd Statystyczny w Szczecinie. (2017). Społeczeństwo informacyjne w Polsce, Wyniki badań statystycznych $z$ lat 2012-2017, Warszawa, http://stat.gov.pl/obszary-tematyczne/nauka-i-technika-spoleczenstwo-informacyjne/spoleczenstwo-informacyjne/spoleczenstwo-informacyjne-w-polscewyniki-badan-statystycznych-z-lat-2012-2017,1,10.html (dostęp: 10.10.2018).

\section{ZAGROŻENIA DLA BEZPIECZEŃSTWA DZIECI W CYBERŚWIECIE}

Dzieci są bardzo kompetentne, jeśli chodzi o korzystanie z nowych technologii. Sprzyja temu wykorzystywanie różnych narzędzi mass mediów przez rodziców, którzy, pochłonięci nadmiarem pracy, pozwalają swoim podopiecznym od ich najmłodszych lat, a nawet pierwszych miesięcy życia, na niekontrolowane korzystanie $\mathrm{z}$ atrakcji świata wirtualnego. Ta nierealna rzeczywistość cechuje się brakiem fizycznych i czasowych granic, nie obowiązują w niej żadne prawa fizyki, nie można jej zlokalizować. Często żyją w niej istoty nierealne, które są stworzone na podobieństwo realnych odpowiedników. Można tam zmienić wiek, płeć, rasę, wykształcenie czy religię, co sprawia, że 
w pewnym momencie obywatele zaczynają odgrywać role, które kiedyś były im obce. Ponadto przebywanie w cyberprzestrzeni, w której małoletni często tracą kontrolę nad czasem, powoduje, że świat wirtualny i jego elementy wywierają na nich coraz większy wpływ. Należy tu zaznaczyć, iż wirtualność posiada atrybuty znacząco wpływające na psychikę dziecka, takie jak:

- Teleobecność, charakteryzowana jako przebywanie małoletniego w odległym środowisku bez fizycznego przemieszczania się.

- Zanurzenie, rozumiane jako wchłanianie dziecka przez wirtualny świat, który odcina je od bodźców świata naturalnego i zastępuje je tymi generowanymi komputerowo.

- Interaktywność w czasie rzeczywistym, polegająca na kontroli i reagowaniu na działania małoletniego (Andrzejewska, 2014, s. 20).

Te cechy powodują, że mały obywatel, który nie jest jeszcze wypełni emocjonalnie ukształtowany i którego system wartości dopiero się buduje, jest bardzo narażony na niebezpieczeństwa związane z przestrzenią wirtualną i jej narzędziami. Wśród tych zagrożeń wyróżnia się m.im.: cyberbullying, seksting, sponsoring, grooming, niebezpieczne gry, propagowanie niewłaściwych zachowań (takich jak anoreksja, bulimia, skrajny nacjonalizm, rasizm, satanizm) czy nawet uzależnianie od mass mediów.

Cyberbullying, określany też mianem cyberprzemocy, to stosowanie agresji przy użyciu technologii informacyjnych i komunikacyjnych, takich jak Internet czy telefony komórkowe. Terminów tych najczęściej używa się w kontekście występowania zachowań przemocowych wśród dzieci i młodzieży (Wrona, 2014, s. 87-88). Agresja jest używana w celu ośmieszania, zastraszania, nękania rówieśników. Problem ten jest trudny, gdyż sprawca nie musi być znany ofierze i przez długi czas może pozostawać anonimowy, co jest jedną z cech świata wirtualnego. Do form cyberbullyingu zalicza się:

- Włamanie na konto e-mail, chat ofiary, lub jej konto na portalach społecznościowych/kradzież tożsamości/personifikację - agresor podaje się za ofiarę i z jej konta wysyła złośliwie wiadomości do znajomych, wchodzi na tzw. „zakazane” dla dzieci strony, np. pornograficzne, erotyczne, w celu ośmieszenia osoby, za którą się podaje. 
- Obrażanie, wyśmiewanie, ubliżanie na forach internetowych - sprawca zakłada kilka profili na tych samych forach co ofiara, a następnie słownie atakuje ją.

- Szantażowanie, groźby i zastraszanie/cybergroźby - sprawca zmusza osobę do konkretnego zachowania po zdobyciu kompromitujących ją materiałów i informacji, ale także pisząc do niej, wyraża swoją złość. Czasami może rozważać spełnienie deklaracji albo grozić popełnieniem samobójstwa.

- Publikacja nieprawdziwych danych/oczernienie - wysyłanie fałszywych okrutnych informacji o ofierze w celu zniszczenia jej dobrej reputacji.

- Rejestrowanie niechcianych zdjęć lub filmów.

- Zapłon, spalanie - wzniecanie konfliktów, kłótni przy użyciu agresywnego i obraźliwego słownictwa.

- Wykluczenie - usunięcie danej osoby z grup online, forów itp.

- Plotkowanie/upublicznianie tajemnic - przekazywanie nieupublicznionych przez ofiarę sekretów, prywatnych informacji.

- Przechytrzenie (zjawisko rudego lisa) - podstępne uzyskanie szkodliwych informacji, które później są ujawniane w celu wyrządzenia szkody danej osobie.

- Cyberstalking - obsesyjne kontrolowanie i śledzenie ofiary w świecie wirtualnym. Również stałe przesyłanie jej agresywnych wiadomości mających na celu wzbudzenie u niej niepokoju (zob. Kotomska, 2012, s. 73-74; Andrzejewska, 2014, s. 122-123; http://www.stopcyberbullying.cba.pl; http://pol.tabby.eu).

Z badań przeprowadzonych w 2007 r. przez Fundację Dzieci Niczyje (obecnie Fundacja Dajemy Dzieciom Siłę) wynika, że aż 52\% małoletnich respondentów oświadczyło, iż miało do czynienia z przemocą werbalną przy użyciu narzędzi takich jak Internet czy telefon. 47\% doświadczyło wulgarnego wyzywania, $21 \%$ było poniżanych, ośmieszanych i upokarzanych, a $16 \%$ zastraszanych. 29\% ankietowanych oświadczyło, iż inna osoba podawała się za nie w sieci wbrew ich woli. Natomiast 57\% badanych w wieku $12-17$ lat przynajmniej raz była obiektem zdjęć lub filmów wykonanych wbrew ich woli. W przypadku 39\% zdarzenie to powtarzało się (Wojtasik, 2017, s. 1-5). 
Przeprowadzone przez Najwyższą Izbę Kontroli w 2017 r. badania wykazały, że z cyberprzemocą zetknęło się 39,5\% uczniów. Prawie połowa badanych małoletnich oświadczyła, że nie zwróciłaby się o pomoc do nikogo w przypadku doświadczenia przemocy. Tylko 19\% poprosiłoby o pomoc rodziców (https://www.nik.gov.pl). Cyberprzemoc jest zjawiskiem niebezpiecznym $\mathrm{z}$ uwagi na różnorodność form, jakie może przybierać oraz stałą ewolucję wraz z rozwojem narzędzi cyberświata. Sprawca często jest bezkarny, a cyberofiara bezradna. U tej ostatniej pojawia się lęk, starach, wycofanie, depresja, ale też agresja.

Innym zagrożeniem jest seksting, rozumiany jako ekshibicjonizm w Internecie. Polega na przesyłaniu nagich lub półnagich zdjęć za pośrednictwem Internetu lub telefonu komórkowego. Zdarza się, że ma zabarwienie erotyczne. Zaczyna się niewinnie poprzez kopiowanie wzorców zaczerpniętych od dorosłych, np. dwoje ludzi przesyła sobie zdjęcia w bieliźnie lub nagie. Problem pojawia się wtedy, gdy zdjęcia, filmy trafiają do szerszego grona odbiorców, a tak się zdarza w przypadku osób małoletnich, których związki uczuciowe nie są jeszcze stabilne i towarzyszy im duża emocjonalność (Andrzejewska, 2014, s. 156-157). W 2014 r. Fundacja Dzieci Niczyje (obecnie Fundacja Dajemy Dzieciom Siłę) przeprowadziła badania, z których wynika, że $34 \%$ badanych przynajmniej raz w życiu otrzymało wiadomość ze zdjęciem nagiej lub półnagiej osoby. 11\% oświadczyło, że sami wysłali takie treści do innych osób. $45 \%$ małoletnich zadeklarowało, że przynajmniej niektórzy $\mathrm{z}$ ich znajomych uczestniczą w zjawisku sekstingu. Jako najczęstszą przyczynę wysyłania tego typu treści wskazywano flirt i chęć zwrócenia na siebie uwagi osoby płci przeciwnej (Wójcik, Makaruk, 2014, s. 4-16). Przyczyn tego zjawiska można dopatrywać się w niedojrzałości emocjonalnej dzieci i braku pełnej świadomości, co może się stać z takimi zdjęciami, filmami i w jaki sposób mogą być wykorzystane przez inne osoby. Małoletni często nie mają świadomości, że nawet usunięte treści pozostawiają ślad w wirtualnej rzeczywistości i kiedyś mogą zostać ujawnione w celu wyrządzenia krzywdy ofierze lub zmuszenia jej do konkretnych działań.

Sponsoring to nowe modne i rozwijające się zjawisko. Definiowane jest jako rodzaj prostytucji łatwiej akceptowalnej przez społeczeństwo, ponieważ jest niewidoczna dla ogółu (Charkowksa, 2010, s. 31). Nie zauważa się już 
problemu społecznego, jaki stanowiły tzw. galerianki, ale to nie znaczy, że przestał istnieć. Młode osoby z galerii i centrów handlowych przeniosły się w świat wirtualny, gdzie łatwiej nawiązać dyskretną znajomość, ukryć się, a nawet utrudnić wykrywalnie przestępstw dotyczących obcowania płciowego z osobą poniżej 15. roku życia. W Internecie po wpisaniu w wyszukiwarce wyrażenie „szukam sponsora” automatycznie otwierają się linki do stron ułatwiających nawiązanie kontaktów damsko-męskich, również tych erotycznych. Pomimo tego, że na stronach istnieje informacja, że mogą z nich korzystać osoby pełnoletnie, nikt tego nie sprawdza. Widoczne też są ogłoszenia typu „Mam 16 lat. Jestem wysoką blondynką. Poszukuję uczciwego młodego Pana, który będzie mnie sponsorował" (https://pomorska.pl/). Sponsoring jest atrakcyjny, gdyż daje szybkie i łatwe korzyści finansowe. Okupione są one jednak negatywnymi skutkami psychicznymi, szczególnie w przypadku młodych osób poznających wartości i kształtujących własną osobowość. W przyszłości może dojść u nich do obniżenia progu molarności, nieprzestrzegania norm społecznych, oziębłości w relacjach z innymi ludźmi, a nawet depresji czy uzależniania od środków psychoaktywnych, ale też i od samego sponsoringu (uzależnianie behawioralne).

Grooming to długotrwały proces mający na celu stopniowe wprowadzanie dziecka w aktywność seksualną przez dorosłego (www.dzieckowsieci.pl). Proces ten, zwany uwodzeniem, złożony jest z pięciu etapów:

- Nawiązanie znajomości z dzieckiem - uwodziciel podszywa się pod rówieśnika i stopniowo zaznajamia z dzieckiem.

- Tworzenie relacji z dzieckiem - pedofil zaprzyjaźnia się z małoletnim. Rozmawia z nim o emocjach, marzeniach, zainteresowaniach. Podsyca w nim przekonanie, że rodzice go nie rozumieją, a tylko na niego może liczyć.

- Ocena ryzyka odkrycia znajomości - dorosły sprawdza sytuację dziecka w domu. Upewnia się, że aktywność dziecka w sieci nie jest kontrolowana przez rodziców. Uczy je, jak ukrywać ich znajomość, np. jak usuwać historię w Internecie.

- Ukazanie dziecku wzajemności relacji, czyli oswajanie z cyberseksem - pedofil przekonuje dziecko, że ich relacja jest wyjątkowa. Powoli przechodzi do rozmów o zabarwieniu erotycznym, przesyła pierwsze zdjęcia pornograficzne. 
- Dążenie do spotkania - uwodziciel chce spotkać się z dzieckiem, a jeśli ono się opiera, posuwa się do szantażu. Może domagać się nagich zdjęć dziecka, grożąc mu powiadomieniem rodziców o ich znajomości. Gdy dostanie zdjęcia, używa ich, by zmusić małoletniego do spotkania (Andrzejewska, 2014, s. 151-152).

Dzieci, które doświadczyły uwodzenia w sieci, ponoszą te same konsekwencje co osoby molestowania seksualnego w życiu realnym. Małoletni zamykają się w sobie, unikają kontaktu, co powoduje, że trudno jest im udzielić pomocy. Ponadto łatwa dostępność telefonu, komputera i brak uwagi ze strony rodziców sprawiają, że problem ten może być zauważony zbyt późno lub w ogóle nie zostanie odkryty przez osoby dorosłe. Groomingowi ulegają osoby, których potrzeby, zwłaszcza emocjonalne, są nie zaspokajane, na które nie zwraca się uwagi - dzieci odrzucone przez rówieśników, mające poczucie niskiej wartości, a jednocześnie ufne. Poszukując relacji, kontaktu, zainteresowania, stają się łatwym celem dla pedofilów. O powadze problemu świadczą też zmiany w Kodeksie karnym, do którego wprowadzono w 2010 r. nowy artykuł, tj. art. 200a:

„\$1. Kto w celu popełnienia przestępstwa określonego w art. 197 zgwałcenie lub wymuszenie do poddania się innej czynności seksualnej $\$ 3$ pkt 2 lub art. 200 obcowanie płciowe z osobą małoletnią lub doprowadzenie jej do poddania się czynnościom seksualnym, jak również produkowania lub utrwalania treści pornograficznych, za pośrednictwem systemu teleinformatycznego lub sieci telekomunikacyjnej nawiązuje kontakt $\mathrm{z}$ małoletnim poniżej lat 15 , zmierzając, za pomocą wprowadzenia go w błąd, wyzyskania błędu lub niezdolności do należytego pojmowania sytuacji albo przy użyciu groźby bezprawnej, do spotkania $\mathrm{z}$ nim, podlega karze pozbawienia wolności do lat 3 .

$\$ 2$. Kto za pośrednictwem systemu teleinformatycznego lub sieci telekomunikacyjnej małoletniemu poniżej lat 15 składa propozycję obcowania płciowego, poddania się lub wykonania innej czynności seksualnej lub udziału $\mathrm{w}$ produkowaniu lub utrwalaniu treści pornograficznych, i zmierza do jej realizacji, podlega grzywnie, karze ograniczenia wolności albo pozbawienia wolności do lat 2" (Ustawa z dnia 6 czerwca 1997 r. Kodeks karny). 
Wykres 2.

Przestępstwa $\mathrm{z}$ art. 200a Kodeksu karnego w latach 2010-2017

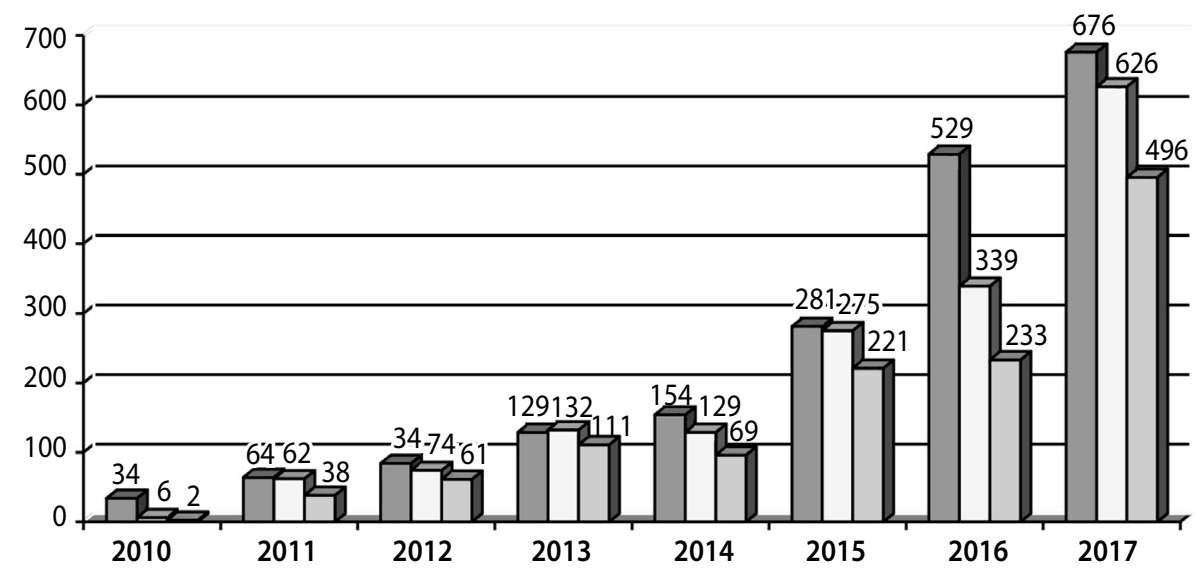

Źródło: badania własne na podstawie http://statystyka.policja.pl/st/kodeks-karny/przestepstwaprzeciwko-6/64005,Uwodzenie-maloletniego-ponizej-lat-15-z-wykorzystaniem-systemuteleinformatyczne.html (dostęp: 28.10.2018).

Od 2015 r. stale wzrasta liczba przestępstw stwierdzonych (w przypadku których potwierdzono, że czyn zaistniał) dotyczących uwodzenia małoletnich. Dane zaprezentowane na wykresie 2 pozwalają zauważyć, że w ostatnich latach nastąpił znaczny wzrost czynów karalnych, co ukazuje skalę problemu. Dokonując analizy przedstawionych danych, należy pamiętać, że istnieje jeszcze „ciemna” liczba obejmująca zachowania przestępcze, które nie zostały ujawnione lub z różnych względów zgłoszone.

Oprócz wymienionego już barku zainteresowania rodziców i niezaspokajania potrzeb emocjonalnych dziecka ważnym czynnikiem warunkującym stanie się ofiarą pedofila jest nieznajomość i brak świadomości zagrożeń cyberświata zarówno ze strony małoletnich, jak i ich opiekunów.

Niebezpieczne gry to kolejne zagrożenie ze strony cyberświata. Gry komputerowe definiowane są jako interaktywne programy, w które można grać pojedynczo lub w więcej osób (Holtkamp, 2010, s. 204). Dobrze dobrane do wieku dziecka i stosowane pod kontrolą rodziców gry mogą mieć pozytywny 
wpływ na jego rozwój. Niestety oprócz „dobrych” gier są także te zawierające treści przemocowe. Dziecko, które w nie gra, nabiera przekonania o powszechności agresji w relacjach międzyludzkich. Niebezpiecznym aspektem takich gier jest oswajanie dziecka z przemocą za sprawą tego, iż zachowania aspołeczne i niebezpieczne są w grach nagradzane. Aktywnie uczestnicząc w świecie wirtualnym, małoletni znieczula się na przemoc. Zaangażowanie grającego potrafi zniwelować dystans tworzący się pomiędzy dzieckiem a światem wirtualnym. Złudzenie pełnego uczestnictwa w kreowaniu tego świata i iluzja samodzielności w tworzeniu go powodują, iż małoletni myśli, że to on decyduje o tym, co się dzieje w grze (Durka, 2012, s. 252). Oswajanie z przemocą, śmiercią, agresją, niestosowaniem się do przepisów prawa sprawia, że małoletni może przenosić do życia realnego zachowania postaci z gry, z którą się utożsamia. Granice pomiędzy cyberświatem a życiem rzeczywistym zacierają się. Dziecko często nie potrafi odróżnić, co jest dobre, a co złe, szczególnie jeśli w grach jest nagradzane za negatywne działania. Gra Złodziej samochodów już w swoim opisie zachęca do aspołecznych zachowań: „Ten złodziej właśnie robi skok życia. Dołącz do niego, gdy kradnie samochody i sieje spustoszenie w tej szalonej grze w wyścigi” (http:// www.gry.pl/gra/zodziej-samochodow_).

Dużym zagrożeniem nie tylko dla psychiki dzieci, ale i ich życia są gry mające na celu doprowadzenie małoletniego do aktów samoagresji, np.: Błękitny wieloryb, Wróżka ognia czy Momo Challenge. Dzieci łatwo ulegają manipulacji i wierzą w informacje przekazywane przez osobę sterującą grą.

Brak kontroli ze strony opiekunów i przyzwolenie na nieograniczone korzystanie z gier może również doprowadzić jednostkę do uzależniania, a także do ukształtowania u niej postawy aspołecznej opartej nie na wartościach moralnych, ale na chęci wygrywania ponad wszystko.

Uzależnianie - nadmierne korzystnie z Internetu to „dysfunkcjonalny wzorzec elementów poznawczych i zachowań związanych z używaniem Internetu, którego rezultatem są utrata kontroli nad zachowaniem (czasem i sposobem korzystania $\mathrm{z}$ Internetu) oraz znaczące pogorszenie w społecznym, zawodowym lub innym istotnym obszarze funkcjonowania podmiotu" (Kaliszewska, 2007, s. 58). Uzależnienie to w literaturze opisuje się jako infoholizm, cyberholizm, cyberuzależninia, uzależnienie od Internetu. Zachowanie te charakte- 
ryzują się wzrostem agresywności, nadpobudliwości, kompulsywnego podejścia do urządzeń cyfrowych czy zaniedbywaniem podstawowych codziennych czynności takich jak: jedzenie, toaleta, sen, odpoczynek (Jędrzejko, Morońska, 2015, s. 62). Z badań przeprowadzonych przez Ninę Ogińską-Bulik w 2016 r. wynika, że 16,3\% młodzieży znajduje się w grupie ryzyka uzależniania od Internetu (Ogińska-Bulik, 2010, s. 61). Obecnie problem ten narasta, ponieważ dostęp do mass mediów mają coraz młodsze dzieci, takie które nie potrafią jeszcze dobrze mówić, a już posługują się telefonami i tabletami. Mówi się już o problemie tabletowych dzieci. Brak świadomości opiekunów co do zagrożeń cyberświata i wykorzystywanie komputerów i telefonów jako elektronicznych niań powoduje, że w pewnym momencie powstanie społeczeństwo niepotrafiące żyć poza światem wirtualnym.

Internet jest źródłem szerokiej wiedzy, która sprzyja rozwojowi jednostki. Niestety posiada też treści niebezpieczne dla małoletnich. Informacje te są ogólnie dostępne. Po wpisaniu w wyszukiwarkę wyrażenia: „jak popełnić samobójstwo" wyświetlają się linki do stron, gdzie można szczegółowo dowiedzieć się, jak skutecznie dokonać tego aktu. Osoby borykające się z problemem bulimii czy anoreksji otrzymają informacje, jak ukryć ten problem przed rodzicami czy terapeutami. Młodzi chłopcy z bigoreksją uzyskają informację, gdzie kupić i jak brać anaboliki i sterydy. W Internecie można dowiedzieć się, których leków i w jaki sposób używać, aby się odurzyć. Powszechnie dostępne są treści pornograficzne, na które nie jest jeszcze gotowy umysł małego dziecka. Grupy rasistowskie i skrajnie nacjonalistyczne w sieci poszukują swoich członków. Tu również działają już sekty. Młody obywatel poszukujący swojej tożsamości, grupy, do której mógłby przynależeć, łatwo ulega manipulacji. Tylko edukacja dotycząca zagrożeń i bezpiecznego przebywania w cyberświecie oraz świadome rodzicielstwo może uchronić dziecko przed staniem się cyberofiarą lub cybersprawcą.

\section{ROLA RODZINY W ZAPEWNIANIU BEZPIECZEŃSTWA DZIECI W CYBERŚWIECIE}

Świat wirtualny jest atrakcyjny dla młodego obywatela i pełen pozytywnych aspektów, które właściwie wykorzystane przyczyniają się do rozwoju emocjonalnego i społecznego osoby małoletniej. Obecnie nie jest możliwe 
funkcjonowanie bez środków masowego przekazu. Ważne jest, aby dziecko potrafiło prawidłowo korzystać z osiągnięć techniki, tak by nie zagrażać sobie i innym. Rodzice jako pierwsi nauczyciele powinni zapoznać małoletniego ze światem wirtualnym, jego dobrodziejstwami, ale i zagrożeniami. W tym celu powinni wykorzystywać dwa nierozerwalne ze sobą procesy - edukację i wychowanie. W kwestii zagrożeń należy mówić o edukacji dla bezpieczeństwa, która jest ważną częścią procesu dydaktyczno-wychowawczego i działań profilaktycznych (Pieczywok, 2011, s. 70). Pojęcie „edukacja dla bezpieczeństwa” definiowane jest współcześnie jako „ogół procesów oświatowo wychowawczych, realizowanych głównie przez rodzinę, szkołę, wojsko, policję, kościoły, środki masowego przekazu, organizacje młodzieżowe i stowarzyszenia, zakłady pracy oraz instytucje państwowe i samorządowe, ukierunkowanych na kształtowanie systemu wartości, upowszechnianie wiadomości i kształtowanie umiejętności ważnych dla zapewnienia bezpieczeństwa” (Stępień, 1999, s. 69). Celem edukacji jest wykształcenie świadomości obronnej pozwalające na zrozumienie istoty i cech różnych zagrożeń oraz ich przewidywanie (Grzyb, 2010, s. 69-70). Edukacja dla bezpieczeństwa jest procesem ciągłym, obejmującym m.in. takie działania jak:

- przekazywanie wiedzy w zakresie występowania zagrożeń,

- kształtowanie bezpiecznych zachowań i postaw,

- motywowanie do podejmowania działań zapewniających bezpieczeństwo,

- upowszechnienia wiedzy i umiejętności z zakresu profilaktyki zagrożeń,

- uświadomienie rodzaju i skali potrzeb w sytuacjach zagrożeń,

- pielęgnowanie wartości dotyczących życia i zdrowia ludzkiego (Pieczywok, 2012, s. 67).

Jednym $\mathrm{z}$ istotnych elementów edukacji dla bezpieczeństwa jest wychowanie. Według Jerzego Kunikowskiego „w znaczeniu węższym przez wychowanie rozumie się zamierzone kształtowanie człowieka, a ściślej - zespołu cech, które stanowią emocjonalno-wolicjonalną sferę osobowości. Inaczej mówiąc, wychowanie będzie szczególnym rodzajem ludzkiej działalności, zmierzającej do wywołania określonych zmian osobowości człowieka (...) 
w znaczeniu szerszym przez wychowanie rozumie się kształtowanie osobowości człowieka, w którym uwzględnia się przede wszystkim przygotowanie go do życia w społeczeństwie. W tym ujęciu mieścić się będzie również wychowanie określane jako proces społeczny, w trakcie którego jednostka zostaje poddana świadomym i celowym wpływom zorganizowanego środowiska, tak by mogła być przygotowana do życia i aby mogła ona osiągnąć optymalny rozwój osobowości” (Kunikowski, 2000, s. 26-27).

Edukacja towarzyszy ludziom przez całe ich życie i rozpoczyna się już od momentu narodzin. Pierwsze procesy związane z edukacją i wychowaniem rozpoczynają się w rodzinie. To na niej ciąży obowiązek kształtowania norm, wartości i zasad postępowania. Odgrywa ona dużą rolę w kształtowaniu osobowości dziecka, gdyż oddziałuje na nie w okresie jego życia, w którym jest ono najbardziej plastyczne i podatne na wpływy otoczenia. Do podstawowych funkcji edukacji zalicza się następujące funkcje: prokreacyjną, wychowawczo-socjalizacyjną, emocjonalno-seksualną, ekonomiczną, stratyfikacyjną, integracyjno-kontrolną, rekreacyjno-towarzyską (Encyklopedia socjologii, 2000, s. 314). Z uwagi na zagrożenia związane z cyberprzestrzenią należy wyróżnić następujące funkcje edukacji:

- wychowawczo-socjalizacyjną, która ma celu zapewnienie ciągłości kultury, wartości, języka, norm i standardów moralności;

- opiekuńczą, pozwalającą na zapewnienie bezpieczeństwa członkom społeczeństwa, szczególnie osobom podatnym na zagrożenia, również te w świecie wirtualnym;

- emocjonalno-seksualną, polegającą na dostarczeniu dzieciom emocjonalnego wsparcia i zaspokojeniu potrzeby miłości, tak by nie musiały szukać wsparcia w sieci;

- integracyjno-kontrolną - w ramach której celem jest kontrolowanie działań poszczególnych członków społeczeństwa, sprawdzanie, na jakie strony wchodzą dzieci, korzystanie z aplikacji do blokownia stron z niebezpiecznymi i szkodliwymi treściami, organizowanie życia dzieci w myśl ustalonych reguł postępowania;

- rekreacyjno-towarzyska, polegającą na organizowaniu czasu wolnego, rozrywki i wypoczynku, a także wprowadzaniu dzieci w świat powiązań towarzyskich w życiu realnym. 
Rodzice powinni wprowadzać dziecko w świat wirtualny, ucząc je poruszania się w nim. Nauka ta powinna odbywać pod ich kontrolą. W celu bezpiecznego korzystania $z$ Internetu opiekunowie stosują często własne oparte na intuicji metody, co powoduje, że w pierwszej fazie wychowania popełniają błędy przedstawione w tabeli 1 .

Tabela 1.

Błędy w modelowaniu relacji dziecko-multimedia

\begin{tabular}{|c|c|}
\hline Błąd wychowawczy & Następstwa i konsekwencje \\
\hline $\begin{array}{c}\text { Całkowite zabranianie dziecku korzystania } \\
\text { z komputera jako konsekwencja naruszenia } \\
\text { ustalonych w domu norm i zasad }\end{array}$ & $\begin{array}{c}\text { Dziecko będzie szukało kontaktu } \\
\text { z komputerem u rówieśników lub } \\
\text { w kawiarence internetowej. Dla ukrycia tego } \\
\text { będzie skłonne do okłamywania rodziców }\end{array}$ \\
\hline $\begin{array}{c}\text { Przekazanie dziecku komputera/ } \\
\text { wnetu bez koniecznego wprowadzenia } \\
\text { psychologicie emocjonalnym, }\end{array}$ & $\begin{array}{c}\text { Dziecko wchodzi w sfery generujące } \\
\text { kwestie, na które jest nie ono przygotowane } \\
\text { emocjonalnie, zatraca granice tego, } \\
\text { co dozwolone i niewskazane }\end{array}$ \\
\hline $\begin{array}{c}\text { Danie dziecku bezgranicznej wolności } \\
\text { w cyberprzestrzeni }\end{array}$ & $\begin{array}{c}\text { Przyspieszone dorastanie, pojawienie się } \\
\text { zachowań charakterystycznych dla dorosłych, } \\
\text { zanik zainteresowania innymi przestrzeniami } \\
\text { niż sieć }\end{array}$ \\
\hline
\end{tabular}

Źródło: M. Jędrzejko, A. Taper. (2010). Jak kształtować kontakt dziecka z multimediami?, Warszawa: ASPRA-JR, s. 69.

Najczęściej rodzice w celu chronienia dziecka przed zagrożeniami świata wirtualnego instalują programy, które mają blokować strony ze szkodliwymi treściami. Ważniejsze jest jednak, aby nauczyć dziecko kulturalnego, krytycznego i ostrożnego korzystania z Internetu. Jadwiga Izdebska wyodrębniła dziesięć zasad, które mają pomóc rodzicom przygotować dzieci do selektywnego, aktywnego i świadomego uczestniczenia w kulturze masowej. Są to:

- Zasada podmiotowości - rodzice odgrywają dużą rolę w organizowaniu dzieciom odbioru treści. Ważne jest, aby uczyć szanowania praw wszystkich członków rodziny i wolności wyboru. Opiekun dyskretnie wprowadza dziecko w różne sytuacje wychowawcze, wyzwalające aktywne, wartościowe uczestnictwo w rodzinno-domowym odbiorze mediów. 
- Zasada zachęcania do rodzinno-domowego odbioru treści za pośrednictwem mediów - motywowanie małoletnich do wspólnego korzystania z mediów i wybierania wartościowych treści.

- Zasada świadomego wyboru treści - kształtowanie umiejętności panowania nad olbrzymią ilością informacji, selekcjonowania ich pod kątem wartości i wyrazu artystycznego. Doradzanie i sugerowanie treści oraz wyjaśnianie, dlaczego warto się z nimi zapoznać. Należy również wskazać i wyjaśnić zagrożenia, jakie niosą nieodpowiednie dla dzieci programy/strony.

- Zasada kompromisu w doborze programów/stron - respektowanie pragnień, potrzeb, życzeń i poszanowanie zainteresowań wszystkich członków rodziny. Kształtowanie kompromisu i poszanowania innych jest sprawą niezbędną dla bezkonfliktowego, korzystnego wychowawczo funkcjonowania rodziny.

- Zasada kształtowania umiejętności wartościowego, kreatywnego odbioru treści - zadaniem rodziców jest uprzystępnianie dzieciom odbieranych treści.

- Zasada ingerowania rodziców - korzystanie z mass mediów może być wykorzystywane przez rodziców jako narzędzie wychowawcze w przypadku systematycznego i umiejętnego kierowania tym procesem poprzez:

- Uzgadnianie z dzieckiem ilości czasu spędzanego przed komputerem/telewizorem, wyeliminowanie korzystania z mass mediów podczas spożywania posiłków czy spotkań rodzinnych. Ważne jest, aby rodzice również stosowali się do tych zasad;

- Inicjowanie odbioru treści wartościowych, społecznie aprobowanych;

- Ograniczanie treści mało korzystnych wychowawczo i zachęcania do zapoznawania się z tymi, które są pozytywne i wartościowe społecznie;

- Przeciwstawianie się oglądaniu przez małoletnich treści przeznaczonych dla widzów dorosłych (przemoc, erotyka);

- Świadome przyjęcie przez opiekunów odpowiedzialności za to, czy dziecko ogląda programy dostosowane do jego wieku, poziomu rozumienia i podatności na perswazję; 
- Rozmowy rodziców z dziećmi na temat scen pokazujących zachowania nieakceptowane społecznie;

- Kierowanie przez rodziców procesem recepcji i percepcji odbieranych treści, zachęcanie dzieci do stawiania pytań;

- Porozumiewanie się rodziców z dziećmi podczas korzystania z komputera, co ma być pomocne w umacnianiu więzi psychicznych i integrowaniu rodziny;

- Wyeliminowanie czynników zagrażających zdrowiu dziecka, takich jak: długi czas korzystania z komputera, nieprawidłowa postawa, zbyt bliska odległość od ekranu;

- Unikanie używania komputera jako „elektronicznej niani”;

- Wyeliminowanie kar za zbyt długie przebywanie przy komputerze, w zamian wzbudzanie u dziecka motywacji do spędzania czasu wolnego w inny atrakcyjny sposób.

- Zasada wykorzystywania wzorów osobowych rodziców - dziecko uczy się poprzez naśladowanie, obserwację rodziców, dlatego powinni oni dbać o to, aby sami przyjmowali właściwe postawy.

- Zasada wykorzystywania zdobytych doświadczeń w procesie wychowawczym - należy wykorzystać media w procesie wychowawczym poprzez realizację funkcji, jakie pełnią media w życiu dziecka: poznawczej, rozrywkowej i odpoczynku. Uzyskane nowe wiadomości, wzory postępowania, normy społeczne powinny wspierać rodziców w ich działaniach.

- Zasada ochrony dzieci przed negatywnym wpływem mass mediów - rodzice mają prawo do zgłaszania żądań, postulatów i wymagań pod adresem mass mediów, gdy zauważą treści szkodliwe.

- Zasada podnoszenia kwalifikacji rodziców w zakresie odbioru treści z mass mediów - zobowiązuje rodziców do ciągłego kształcenia się w dziedzinie nowych technologii i rozwoju świata wirtualnego z uwzględnianiem niebezpieczeństw i zagrożeń dla rodziny (zob. Nowicka, 2012, s. 174-178).

Stosując powyższe zasady, rodzice powinni zwracać uwagę na emocje dziecka, jego potrzeby. Ważne jest, by uczestniczyli w jego życiu, również tym 
wirtualnym. Opiekunowie powinni nauczyć małoletniego korzystania z mass mediów, kulturalnego, bezpiecznego zachowania w sieci i poprawnej weryfikacji proponowanych mu treści.

\section{ZAKOŃCZENIE}

Dzisiejszy świat stale podlega zmianom, a wraz z nim zmienia się kultura masowa. Obok siebie istnieją dwa światy: realny i wirtualny, który jest atrakcyjny, fascynujący zwłaszcza dla dzieci. Niesie nowe treści, nowe doświadczenia, nowe przeżycia. Jest szansą dla rozwoju indywidualnego jednostki i społeczności, ale też stwarza zagrożenia. Rodzina jako pierwsza grupa społeczna, w której przebywa dziecko i z którą się identyfikuje, zobowiązana jest do wychowania go zgodnie ze społecznie aprobowanymi normami i wartościami. W ramach stałej edukacji powinno się przedstawiać pozytywne i negatywne aspekty cyberprzestrzeni i bezpiecznego poruszania się w niej. Rodzic nie tylko ma kontrolować ruchy podopiecznego $\mathrm{w}$ sieci, blokować strony $\mathrm{z}$ treściami niebezpiecznymi, ale powinien nauczyć go samodzielnego, rozumnego korzystania $z$ Internetu. Dziecko powinno znać zagrożenia, przewidywać je i im przeciwdziałać. Rodzic musi wyposażyć dziecko w wiedzę i umiejętności pozwalające na świadome, krytyczne i bezpieczne poruszanie się w cyberprzestrzeni. „W przypadku dzieci szczególnie ważnymi osobami w ich życiu są rodzice, na których spoczywa obowiązek przygotowania swoich dzieci do właściwego i racjonalnego korzystania z mediów. To dorośli są odpowiedzialni za bezpieczeństwo dzieci i za jak najlepsze przygotowanie ich do tego, aby mogły o siebie zadbać" (Sałysz, Arcimowicz, 2009, s. 97), a także by nie stały się zagrożeniem dla innych. Należy zaznaczyć, że to nie Internet, telefon stanowią zagrożenie, ale osoby, które nie potrafią z nich prawidłowo korzystać. Za każdym zagrożeniem powstałym w świecie wirtualnym kryje się działanie człowieka, wobec którego w przeszłości popełniono błędy wychowawcze lub pozostawiono go samemu sobie, pozwalając na swobodne kształtowanie się jego osobowości. Dlatego tak ważna jest edukacja i świadomy proces wychowawczy, który powinien się zacząć w pierwszych dniach życia dziecka. Każdy rodzic w swoich działaniach powinien kierować się wychowaniem świadomego, prospołecznego obywatela umiejącego korzystać z rozwoju techniki, ale posiadającego też wiedzę na temat zagrożeń cyberprzestrzeni i możliwości im przeciwdziałania. 


\section{Literatura}

Andrzejewska, A. (2014). Dzieci i młodzież w sieci zagrożeń realnych $i$ wirtualnych. Aspekty teoretyczne i empiryczne, Warszawa: Difin. ISBN 9788379302277.

Andrzejewska, A. (2014). Nowe kompetencje nauczycieli w zakres możliwości i niebezpieczeństw cyberprzestrzeni. W: J. Bednarek, A. Andrzejewska (red.), Zagrożenia cyberprzestrzeni i świata wirtualnego, Warszawa: Difin. ISBN 9788379302284.

Bednarek, J. (2012). Cyberprzestrzeń i roboty humanoidalne nowym wyzwaniem edukacji. W: J. Morbitzer, E. Musiał (red.), Człowiek, media, edukacja, Kraków: Katedra Technologii i Mediów Edukacyjnych, Uniwersytet Pedagogiczny im. KEN. ISBN 9788372717368.

Bokszański, Z., \& Domański, H. (2000). Encyklopedia socjologii, t. 3, O-R, kom. red. Z. Bokszański i in., red. nauk. Henryk Domański i in., Warszawa: Oficyna Naukowa.

Charkowksa, K. (2010). Zjawisko prostytucji $w$ doświadczeniach prostytuujących się kobiet, Kraków: Impuls. ISBN 9788375872767.

Durka, G. (2012). Rola gier komputerowych w życiu młodzieży. W: S. Bębas, J. Plis, J. Bednarej (red.), Patologie w cyberświecie, Radom: Wyższa Szkoła Handlowa w Radomiu. ISBN 9788362491223.

Gogołek, W., Cetera, W. (2014). Leksykon tematyczny. Zarzadzanie, IT, Warszawa: Wydawnictwo Wydziału Dziennikarstwa i Nauk Politycznych UW. ISBN 9788363183585.

Grzyb, J. (2010). Edukacja dla bezpieczeństwa - cele i treści kształcenia, programy nauczania. W: W. Kaczmarek, R. Socha, J. Grzyb (red.), Wybrane zagadnienia edukacji dla bezpieczeństwa, Ełk: Mazurski Ośrodek Kształcenia Nauczycieli. ISBN 9788393202706 .

Holtkamp, J. (2010). Co ogłupia nasze dzieci?, Kraków: Wydawnictwo Uniwersytetu Jagiellońskiego. ISBN 9788375802122.

Izdebska, J. (2000). Dziecko w rodzinie u progu XXI wieku: niepokoje i nadzieje, Białystok: „Trans Humana”.

Jędrzejko, M., Taper, A. (2010). Jak kształtować kontakt dziecka $z$ multimediami?, Warszawa: ASPRA-JR, ISBN 9788375452136.

Jędrzejko, M.Z, Morońska, D. (2015). Cyberzaburzenia-cyberuzależninia. W: M.Z. Jędrzejko, M. Kowalski, B.P. Rosik (red.), Uzależnienia behawioralne. Wybrane aspekty, Pułtusk: Wydawnictwo Akademii Humanistycznej im. Aleksandra Gieysztora. ISBN 9788375492248. 
Kaliszewska, K. (2007). Nadmierne używanie internetu. Charakterystyka psychologiczna, Poznań: Wydawnictwo Uniwersytetu Adama Mickiewicza. ISBN 9788323218500 .

Kitler, W. (2011). Bezpieczeństwo Narodowe RP: podstawowe kategorie, uwarunkowania, system, Warszawa: Akademia Obrony Narodowej. ISBN 9788375231595.

Kotomska, M. (2012). Przemoc wirtualna, jej skutki i metody przeciwdziałania. W: S. Bębas, J. Plis, J. Bednarej, Patologie w cyberświecie, Radom: Wyższa Szkoła Handlowa w Radomiu. ISBN 9788362491223.

Kunikowski, J. (2000). Wiedza obronna, Warszawa: Ministerstwo Obrony Narodowej. ISBN 8388185292.

Leszczyński, M. (2011). Bezpieczeństwo społeczne Polaków wobec wyzwań XXI w., Warszawa: Difin. ISBN 9788376415284.

Loranty, K. (2004). Bezpieczeństwo społeczne Rzeczypospolitej Polskiej, Warszawa: Akademia Obrony Narodowej.

Niedziółka, I. (2014). Dziecko jako konsument, Journal of Modern Science, 20(1), 419-430.

Nowak, E., Nowak, M. (2011). Zarys teorii bezpieczeństwa narodowego, Warszawa: Difin. ISBN 9788376414850.

Nowicka, E. (2012). Edukacja medialna i osobowość a wychowanie dzieci i młodzieży. W: T. Lewowiecki, B. Siemieniecki (red.), Cyberprzestrzeń i edukacja, Toruń: Wydawnictwo Adam Marszałek. ISBN 9788377803264.

Ogińska-Bulik, N. (2010). Uzależnianie od czynności. Mit czy rzeczywistość?, Warszawa: Difin. ISBN 9788376412559.

Pieczywok, A. (2011). Wybrane problemy z zakresu edukacji dla bezpieczeństwa. Konteksty, zagrożenia, wyzwania, Warszawa: Akademia Obrony Narodowej. ISBN 9788375231625.

Pieczywok, A. (2012). Edukacja dla bezpieczeństwa wobec zagrożeń i wyzwań wspótczesności, Warszawa: Akademia Obrony Narodowej. ISBN 9788375231977.

Sałysz, A. Arcimowicz, B. (2009). Przyjaciele w internecie, Gdańsk: Gdańskie Wydawnictwo Psychologiczne. ISBN 9788374892438.

Sitek, B. W. (2018). Dynamika źródet powstawania prawa od prawa rzymskiego do cyberprzestrzeni, Journal of Modern Science, 39(4), 185-199. https://doi. org/10.13166/jms/103109

Stępień, R. (1999). Edukacja obronna (edukacja dla bezpieczeństwa). W: R. Sępień (red.), Leksykon pojęć dydaktyczno-wychowawczych dowódcy, Warszawa: Bellona. ISBN 8311090653. 
Supińska, J. (1991). Dylematy polityki społecznej, Warszawa: Uniwersytet Warszawski, ISBN 834085812.

Wojtasik, Ł. (2007). Przemoc rówieśnicza a media elektroniczne, raport z badań, Warszawa: Fundacja Dzieci Niczyje i Gemius.

Wójcik, Sz., Makaruk, K. (2014). Seksting wśród polskiej młodzieży. Wyniki badania ilościowego, Warszawa: Fundacja Dzieci Niczyje.

Wrona, A. (2014). Ciemna strona sieci - zagrożenia internetowe oraz ich konsekwencje dla uczniów. W: J. Bednarek, A. Andrzejewska (red.), Zagrożenia cyberprzestrzeni i świata wirtualnego, Warszawa: Difin. ISBN 9788379302284.

\section{Akty prawne}

Ustawa z dnia 6 czerwca 1997 r. Kodeks karny (Dz.U. z 1997 r. nr 88, poz. 553).

\section{Źródła internetowe}

http://pol.tabby.eu/co-to-jest-cyberbullying.html (dostęp: 28.10.2018).

http://www.stopcyberbullying.cba.pl/index.php?option=com_content\&view=article\&id=2\&Itemid $=($ dostęp: 28.10 .2018$)$.

https://www.nik.gov.pl/aktualnosci/nik-o-cyberprzemocy-wsrod-dzieci-i-mlodziezy.html (dostęp: 28.10.2018).

https://pomorska.pl/oralny-moze-byc-bez-gumki-w-toruniu-sponsoring-wsrodnastolatek-przybiera-coraz-wieksze-rozmiary/ar/7140951 (dostęp: 28.10.2018).

http://stat.gov.pl/obszary-tematyczne/nauka-i-technika-spoleczenstwo-informacyjne/spoleczenstwo-informacyjne/spoleczenstwo-informacyjne-w-polsce-wynikibadan-statystycznych-z-lat-2012-2017,1,10.html (dostęp: 10.10.2018).

www. dzieckowsieci.pl (dostęp: 28.10.2018).

http://statystyka.policja.pl/st/kodeks-karny/przestepstwa-przeciwko6/64005,Uwodzenie-maloletniego-ponizej-lat-15-z-wykorzystaniem-systemuteleinformatyczne.html (dostęp: 28.10.2018).

http://www.gry.pl/gra/zodziej-samochodow (dostęp: 28.10.2018). 